\title{
Customer Satisfaction as an Influence Mediation of Service Quality, Financial Considerations, Convenience Toward Switching Behavior (Study on Customer of PT. Bank Central Asia Tbk, Branch Malang)
}

\author{
Kanti Rahayu, Rofiaty, Sudjatno \\ ${ }^{123}$ Faculty of Economy and Business Universitas Brawijaya, Malang, Indonesia
}

\begin{abstract}
This research has discussed switching behavior problem mediated by customer satisfaction. The aims of this research are to understand customer satisfaction dimension which are consist of service quality, financial considerations, and convenience in its influence towards switching behavior, by using survey of 200 inactive customer to verify research hypothesis. Data analysis using Partial Least Square (PLS) analysis methods toward customer of PT. Bank Central Asia, Tbk branch Ma lang. This result research has shown that service quality significantly influence to $s$ witching behavi or financial consideration significantly influence to switching behavior in term of low savings rate dimension, but insignificant to administration fee and loan interest, convenience insignificantly influence to switching behavior in terms of ATM and service hours. New findings that convenience is also i nvolve provided parking l ot, almost in every branch office of BCA in Malang complaining the same thing.
\end{abstract}

Keywords: switching behavior, service quality, financial considerations, convenience, customer Satisfaction.

\section{INTRODUCTION*}

In this advance industry competition, company must have positive development continuously, so they can always give the best service to their customer. Banking as one of financial service sector is very substantial in supporting nation development activity, also taking their part as people fund collector and loan distributor. in its implementation, is really depend on their customer, who demand a perfection in the whole service.

According [1], bank define as Financial institution which are collecting fund from people and distributing to them while giving another bank services. Based on Act number 10 year 1998 about banking, explains bank is business entity which collecting fund from people and distributing fund to people in form of loan and other forms to increase people standard of living. Government role to strengthen banking industry sector is for keeping endurance of banking industry and also win a competition in Asian Economic Community. Experts staff of Finance ministry in policy, finance service regulation and capital market Isa Rachmatarwata in Investor [2], tated that banking industry is strong enough and capable to give significant support towards economic growth.

Correspondence address:

Kanti Rahayu

Email : kanti_rahayu@bca.co.id

Address: Faculty of Economy and Business Universitas Brawijaya, Malang, Indonesia
Last year, said Isa, banking sector gave a roung $4 \%$ in Indonesia Gross Domestic Growth. Government part in this matter was directing banking economy activity by managing bank function, which are divided in to 3 functions; first, bank as a central bank, in this term is charged by Indonesian Bank, its functions are to manage money distribution, relationship among banks, and the last place for bank to ask loan. Second, bank as a general bank, its function is to serve people with any kind of banking services, this bank is divided in bank with foreign exchange service and bank with no foreign exchange service. Third, bank as Loan People Bank.

Switching behavior according [3], explains that losing customer in banking industry has a disserve effect in bank market and profit, 75\% the reason of switching cost is moving places According [4], switching behavior is a conditions of rumors which makes transfer decision. According [5], is stated that switching behavior is people behavior to move from one services provider to a nother. From definitions above we can conclude that switching behavior is a certain condition which caused customer move to another service provider in the same product or service. 
From that definition, switching behavior mostly influenced by customer satisfaction. About how the service meet their expectation or not. Just like describe by According [6], mentioned that satisfaction are excitement and disappointment feeling from comparing product performance and its expected result. According [7], explaine that substance of business purpose are to create and keep the customer, the advantage of the satisfaction itself is able to maintain customer loyalty, so it will create re-purchasing activity which can increase company income, beside the existence of word of mouth can be positive for the company image. It will be good for company to receive complain and critics from customer as a user, to make the service and product quality meet their expectation, to create customer satisfaction.

Customer satisfaction is a valuable condition in banking business because it will create customer loyalty, however dissatisfaction lead to low loyalty in all industries even can cause switching behavior and es pecially in retail banking,according [8], that the relation between switching and satisfaction is significant influenced by service quality. To achieve customer satisfaction according [1], needs to pay attention in service quality, start from staff who provide the service until the product, and after sell service.

According [3], customer satisfaction dimension influenced by financial consideration is $11,7 \%$ consist of $6 \%$ interest earnings and $5.7 \%$ interest payment, financial definition is focused on emerge cost to gain advantage from sacrifice service delivery, which are deposit interest cost and loan interest cost. According [9], stated that bank in running its business gain profit from deviation of interest cost gave to customer in form of deposit and interest cost received from customer in form of loan and also from giving another banking services. According [6], explains that total customer cost is batch of cost spent by customer to evaluate, receive, use and reject a certain market offer including monetary cost, time, energy and psychological cost. Financial consideration is sacrifice which make hard for customer to change service provider [10]. Bank customer have a high probability to do switching behavior because of financial consideration, actually towards low rate of interest of deposit and high rate of interest towards loan and credit card, also rejection of Ioan application [3].

Convenience in this matter is comfortable feeling of customer, beside financial consideration. In this research, [3], convenience has two elements which are convenience involving ATM and operational banking work hours. But according [11], convenience divided in two categories which are location and work hours, it is includes long queue, not on time appointment and delivery. Based on this reason, every bank will try to increase customer satisfaction, whether staff factor, product, cost and convenience. Even though today phenomenon, switching cost happen for a certain reason. For example: PT. BCA, Tbk have a condition for minimum Ioan application is Rp. 500.000.000,- but people only need Rp. 20.000.000,- so the customer trying to find a nother bank which is able to give them Ioan according to their needs. Another example, if an employee has a deposit account in BRI bank, but for salary payment the company has already worked together with BNI bank, so, they have no choice to open an account in that bank. One more example is customer must be open an account in sharia bank decided by the government to collect their hajj fund, so the customer must open different account if they do not have an account in sharia bank.

Based on business phenomenon and research gap above, the researcher continue this research to find out what kind of factors influence in customer of PT. BCA, Tbk branch Malang in deciding the bank that meet their expectation, and why customer doing switching behavior.

According to the background above, the problem formulations are:

1. Does service quality significantly influence switching behavior towards customer of PT. BCA, Tbk branch malang?

2. Does customer satisfaction mediating service quality relationship towards switching behavior to customer of PT. BCA, Tbk branch malang?

3. Does financial considerations significantly influence switching behavior towards customer of PT. BCA, Tbk branch malang?

4. Does customer satisfaction mediating financial considerations relationship towards switching behavior to customer of PT. BCA, Tbk branch malang?

5. Does convenience significantly influence switching behavior towards customer of PT. BCA, Tbk branch malang?

6. Does customer satisfaction mediating convenience relationship towards switching behavior to customer of PT. BCA, Tbk branch malang? 
7. Does customer satisfaction significantly influence switching behavior towards customer of PT. BCA, Tbk branch malang?

Research aims

According to problem formulation above, the aims of the research are:

1. To examine and analyze influence of service quality towards switching behavior of PT. BCA, Tbk branch malang customer.

2. To examine and analyze influence of service quality towards switching behavior through customer satisfaction as mediation of PT. BCA, Tbk branch malang customer.

3. To examine and analyze influence of financial consideration towards switching behavior of PT. BCA, Tbk branch malang customer.

4. To examine and analyze influence of financial consideration towards switching behavior through customer satisfaction as mediation of PT. BCA, Tbk branch malang customer.

5. To examine and analyze influence of convenience towards switching behavior of PT. BCA, Tbk branch malang customer.

6. To examine and analyze influence of convenience towards switching behavior through customer satisfaction as mediation of PT. BCA, Tbk branch malang customer.

7. To examine and analyze influence of cus tomer satisfaction towards switching behavior of $\mathrm{Pt}$. BCA, Tbk branch malang customer.

\section{MATERIAL AND METHOD}

This research has us ed quantitative descriptive approach which pointed to theory and concept examination through variable measurement in matrix and number. That is according to data analysis procedure and statistic tools to measure and examine hypothesis [12],. This also has used survey methods to get a decided information and population [13], The research has done in Malang City and region, east java, Indonesia in PT. BCA, Tbk during 1 month, for the whole July 2016 whether in branch office, supporting branch office, and cash office. The technic used in analyzing statistic multivariate data has known as PLS (Partial Least Square). PLS smart program 2.0 version [14].
PICTURE 1.1 CONCEPTUAL FRAMEWORK RESEARCH

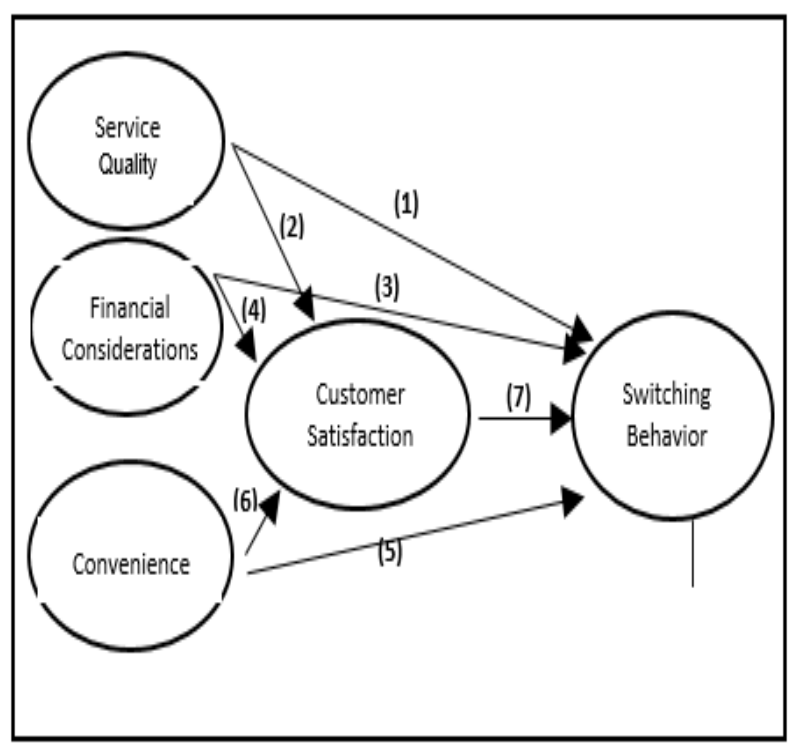

\section{Data Collection}

This research has used primary and secondary data, primary data obtained by direct interview with customer in PT. BCA, Tbk. Data sorce came from branch office da ta base according to inactive custumer data report in the last two years. The researcher had visited those customer to fill in the questioner through interview, so the data result is pure from customer. Secondary data is data obtained through online website and library. Primary data which are came from 200 respondent who fill in the questioner through direct interview became a research sample.

Variable measurement technic in this research used questioner contain of questions has to be answered by respondent by choosing one of those suitable answers, quantitative questioner has used 1 through 5 litkert scale, which are 1) very disagree 2) disagree 3) quite agree 4) agree and 5) very agree, especially for independent variables like service quality that has staff and product dimension, financial consideration with interest earnings and interest payment dimension, convenience with ATM dimension, branch office and work hours. So did variable questioner with customer satisfaction mediation. However, switching behavior as dependent variable measure used 1 through 5 litkert scale which are 1) very impossible to switch, 2) impossible to switch, 3) quite possible to switch, 4) possible to switch, 5) very possible to switch. 
RESULT AND DISCUSSION

Table 1.1 Respondent Characteristic

\begin{tabular}{|l|l|}
\hline Characteristic & $\begin{array}{l}\text { Frequency } \\
\text { (\%) }\end{array}$ \\
\hline GENDER : & \\
Male & $45 \%$ \\
Female & $55 \%$ \\
AGE & \\
$<20$ & \\
$21-30$ & $3 \%$ \\
$31-40$ & $32 \%$ \\
$41-50$ & $29.5 \%$ \\
$51-60$ & $22 \%$ \\
$>60$ & $11.5 \%$ \\
MARITAL STATUS & $2 \%$ \\
Single & \\
Married & \\
Widow/Widower & $29 \%$ \\
EDUCATION BACKGROUND & $68 \%$ \\
High School & $3 \%$ \\
Bachelor Degree & \\
JOB & \\
Entrepreneur & \\
Private employees & $33.5 \%$ \\
SALARY & \\
$<15$ juta & \\
$15-50$ Juta & \\
$50-400$ juta & \\
$<400$ juta & \\
AIMS IN MAKING AN ACCOUNT \\
Transaction & \\
Deposit & $5 \% .5 \%$ \\
& \\
\hline
\end{tabular}

\section{Research Instrument Examination}

2.1 Construct validity examination Pengujian Construct validity examination has done by counting convergent validity and discriminant validity. Convergent has found out through loading factor. An instrument stated that completing convergent validity examination if it has loading factor up to 0.5 [15]. In this research has found that all the loading factors item that measure service quality variable, financial consideration, convenience, customer satisfaction and switching behavior is more than
0.5. Therefore, all item which are measure variable above is valid.

Besides loading factor, validity convergent also can be seen through Average Variance Extracted (AVE) and communality. An instrument said that has completed convergent validity examination if it has Average Variance Extracted (AVE) and communality up to 0.5 [15]. the result of convergent validity examination present in this table below:

Table 1.2 Convergent Validity Testing Results

\begin{tabular}{|c|c|c|c|}
\hline & AVE & Communality & Information \\
\hline Service Quality & 0,598 & 0,598 & Valid \\
\hline $\begin{array}{c}\text { Financial } \\
\text { Consideration }\end{array}$ & 0,895 & 0,895 & Valid \\
\hline $\begin{array}{c}\text { Convenience } \\
\text { Customer }\end{array}$ & 0,635 & 0,635 & Valid \\
\hline Satisfaction & 0,679 & 0,679 & Valid \\
\hline $\begin{array}{c}\text { Switching } \\
\text { Behavior }\end{array}$ & 0,899 & 0,899 & Valid \\
\hline
\end{tabular}

Source : Processed primary data (2016)

\subsection{Construct reliability examination}

Measurements can be used to examine construct reliability are cronbach alfa and composite reliability. Examination criteria stated that if composite reliability more than 0.7 [16], dan cronbach alfa is more than 0.6 the construct is reliable.

Examination result of composite reliability and cronbach alfa can be seen through conclusion in the table below:

Table 1.3 Result of Construct Reliability Examination

\begin{tabular}{|c|c|c|c|}
\hline & $\begin{array}{c}\text { Composite } \\
\text { Reliability }\end{array}$ & $\begin{array}{c}\text { Cronbach } \\
\text { Alpha }\end{array}$ & Keterangan \\
\hline Service Quality & 0.961 & 0.957 & Reliabel \\
\hline $\begin{array}{c}\text { Financial } \\
\text { Consideration }\end{array}$ & 0.971 & 0.961 & Reliabel \\
\hline Convenience & 0.945 & 0.942 & Reliabel \\
\hline $\begin{array}{c}\text { Customer } \\
\text { Satisfaction }\end{array}$ & 0.894 & 0.840 & Reliabel \\
\hline $\begin{array}{c}\text { Switching } \\
\text { Behavior }\end{array}$ & 0.978 & 0.975 & Reliabel \\
\hline
\end{tabular}

Source: Processed primary data (2016) 
3. Partial Least Square (PLS) Analysis

3.1 Path Diagram Development

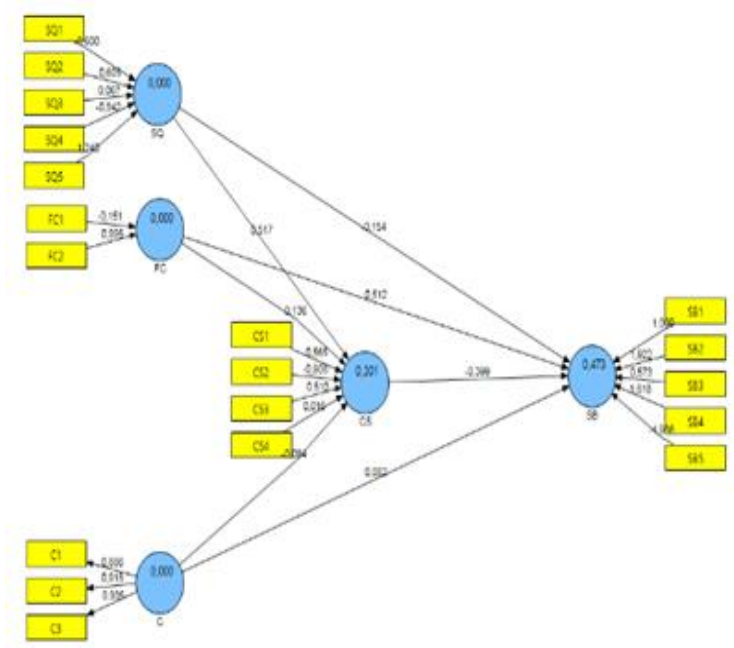

Picture 3.1 Goodness of Fit Inner Model

\subsection{Goodness of Fit Inner Model}

Goodness of fit model used to find out how capable endogen variable to explain the variety of exogenous variable, or in other word to find out how big the contribution of exogenous variable toward endogen variable. Goodness of Fit Model in PLS analysis has been done using Q-Square predictive relevance $\left(Q^{2}\right)[16]$.

Goodness of Fit Model result has concluded in the table below:

Table 1.4 Goodness of Fit Model Result

\begin{tabular}{|l|l|}
\hline Variabel & $\boldsymbol{R}^{\mathbf{2}}$ \\
\hline Customer Satisfaction & 0.301 \\
\hline Swithcing Behavior & 0.473 \\
\hline $\mathrm{Q}^{2}=1-\left(1-\mathrm{R}_{1}{ }^{2}\right)\left(1-\mathrm{R}_{2}{ }^{2}\right) \rightarrow \mathrm{Q}^{2}=1-(1-$ \\
$0.301)(1-0.473)=0.632$
\end{tabular}

Source: Processed primary data (2016)

\subsection{Hypothesis Examination}

Significance examination used for examining presence or absence of exogenous variabl influence toward endogen variable. Criteria examination stated that if the score of T-statistic $\geq$ T-table (1.96)[15], exogenous variable will significantly influence endogen variable. Significance examination result can be seen in the table below:

Table 1.5 Hypothesis examination result

\begin{tabular}{|l|c|c|c|c|c|c|}
\hline Hypothesis & $\begin{array}{c}\text { Exogenous } \\
\text { variable }\end{array}$ & $\begin{array}{c}\text { Endogen } \\
\text { variable }\end{array}$ & $\begin{array}{c}\text { Direct } \\
\text { Coefficient }\end{array}$ & $\begin{array}{c}\text { Standard } \\
\text { Error }\end{array}$ & T Statistics & Hasil pengujian \\
\hline Hypothesis 1 & Service Quality & $\begin{array}{c}\text { Switching } \\
\text { Behavior }\end{array}$ & -0.154 & 0.067 & 2.309 & Significant \\
\hline Hypothesis 2 & Service Quality & $\begin{array}{c}\text { Customer } \\
\text { Satisfaction }\end{array}$ & 0.517 & 0.118 & 4.384 & Significant \\
\hline Hypothesis 3 & $\begin{array}{c}\text { Financial } \\
\text { Consideration }\end{array}$ & $\begin{array}{c}\text { Switching } \\
\text { Behavior }\end{array}$ & 0.512 & 0.112 & 4.565 & Significant \\
\hline Hypothesis 4 & $\begin{array}{c}\text { Financial } \\
\text { Consideration }\end{array}$ & $\begin{array}{c}\text { Customer } \\
\text { Satisfaction }\end{array}$ & 0.136 & 0.060 & 2.257 & Significant \\
\hline Hypothesis 5 & Convenience & $\begin{array}{c}\text { Switching } \\
\text { Behavior }\end{array}$ & 0.082 & 0.042 & 1.933 & Insignificant \\
\hline Hypothesis 6 & Convenience & $\begin{array}{c}\text { Customer } \\
\text { Satisfaction }\end{array}$ & -0.084 & 0.062 & 1.354 & Insignificant \\
\hline Hypothesis 7 & $\begin{array}{c}\text { Customer } \\
\text { Satisfaction }\end{array}$ & $\begin{array}{c}\text { Switching } \\
\text { Behavior }\end{array}$ & -0.399 & 0.125 & 3.196 & Significant \\
\hline
\end{tabular}

3.3 Mediation characteristic examination Mediation characteristic examination is to find out direct influence of independent variable toward dependent variable. If the score of VAF above $80 \%$ means that VAF categorize as a full mediation, if it is around $20 \%$ to $80 \% \mathrm{VAF}$ categorize as a partial mediation, but if it less than $20 \%$ means that there is no mediation effect [17]. The result is in table below: 
Table 1.6 Mediation characteristic examination result

\begin{tabular}{|c|c|c|c|c|c|c|}
\hline Exogenous & Mediation & Endogen & Direct & Indirect & Total & VAF \\
\hline Service Quality & Customer Satisfaction & Switching Behavior & -0.154 & -0.206 & -0.360 & 0.572 \\
\hline $\begin{array}{c}\text { Financial } \\
\text { Consideration }\end{array}$ & Customer Satisfaction & Switching Behavior & 0.512 & -0.054 & 0.458 & (0.118) \\
\hline Convenience & Customer Satisfaction & Switching Behavior & 0.082 & 0.033 & 0.115 & 0.290 \\
\hline
\end{tabular}

Source: Processed primary data (2016)

\section{CONCLUSION}

Based on problem formulation, aims and discussion in this research about switching behavior which directly or indirectly influenced by customer satisfaction through service quality, financial consideration and convenience variables, it can be conclude that:

1. Service quality has significantly influence toward switching behavior. Indicator that influence service quality variable with a negative weight is in tangibles and assurance indicators, while for reliability, responsiveness and Empathy indicator are positive. It has shown that respondent in this research do not have any obstacle when transacting in PT. BCA, Tbk branch malang even towards staff responsive when transacting, explain about the product and its advantage also toward the closeness with customer, especially if there was a complain they can manage to resolve it well and fast. This research also has a negative weight on tangibles indicator (inconsistency of security staff to welcoming and saying thank you before and after customer transacting in front door) and assurance (teller and CSO staff, especially for new staff sometime has less thorough to do transaction activity)

2. Service quality significantly and negatively influence toward customer satisfaction. The better customer satisfaction because service quality increase the lower switching behavior happen, it is a significant reduction. According to this research VAF score to examine influence of service quality variable toward customer satisfaction is 0.572 or $57.2 \%$. That score is in around $20 \%$ to $80 \%$, so it stated that customer satisfaction able to partially mediate relationship between service quality variable toward switching behavior. It shows that customer came to PT. BCA, Tbk feels satisfy with the service quality, so the customer will not do switching behavior.

3. There is significantly influence of financial consideration toward switching behavior. It is because most of the customer disagree if the deposit interest rate in PT. BCA, Tbk higher than another bank. So they will move to another bank if they give a higher interest in deposit.

4. Financial consideration is insignificantly influence toward switching behavior through customer satisfaction. Therefore, customer satisfaction is unable to mediate financial consideration toward switching behavior. Indirect effect coefficient of financial consideration toward switching behavior through customer satisfaction is 0,054 , it means the influence is negative. So, the more negative of customer satisfaction caused by the increase of financial consideration (administration fee and high loan interest) tend to increase switching behavior, but it is insignificant. VAF score to examine influence of financial consideration variable through customer satisfaction is $-11.8 \%$, means that customer satisfaction is unable to mediate financial consideration toward switching behavior. It is because respondent is not satisfy with low interest deposit in PT. BCA, Tbk branch malang, so if there is a bank gave them a higher interest deposit they will still do switching behavior.

5. Convenience insignificantly influence toward switching behavior. It is because PT. BCA, Tbk gave a convenience service because far position of ATM from people places can be resolved by e-banking serviceand ATM in public area, so the customerfeel comfortable.

6. Convenience has insignificantly influence toward switching behavior through customer satisfaction. PT. BCA, Tbk gave the customer convenience regarding to 
geographic position and work hours, and they add more by giving E-channel/Ebanking solution. Indirect effect coefficient of convenience is 0.033 , it is stated that convenience is positively and insignificantly influence toward switching behavior through customer satisfaction. It means that the higher customer satisfaction because enhancement of convenience (ATM disruption has resolved) tend to decreasing switching behavior, but insignificant. VAF examining of convenience variable toward switching behavior through customer satisfaction, get a $29 \%$ result, so it stated that customer satisfaction variable partially mediate the relationship of convenience variable toward switching behavior.

7. Customer satisfaction is significantly influence toward switching behavior. Direct effect coefficient of customer satisfaction toward switching behavior is 0.399 , it stated that customer satisfaction is negatively and insignificantly influence toward switching behavior. It means that the better customer satisfaction is tend to decrease switching behavior, but it is insignificant.

\section{SUGGESTIONS}

Based on the research results and conclusions are presented, it is necessary to repair and attention, including suggestions submitted are:

1. To enter the world of banking competition in Malang, provision should be reviewed interest on savings or deposits especially against customers great balance so that customers do not switch to other bank interest on savings or deposits from larger.

2. To improve the Service Quality primarily associated Staff serving both Front Office and Head of Division Operations accompanying the Front Office, especially so given training about the product and how to make up yourself so that it looks more attractive, fresh and confident. Additionally Staff will be more reliable in serving its customers.

3. Provided adequate parking areas, es pecially for the security of its customers, specially customers who deposit large amounts and foster ongoing relationships with customers, so the lack of parking areas may be slightly reduced because the intertwined relationships that are sustainable.

\section{Research Limitation}

This research has gone through any conditions in scientific research and repeated improvement, but there are some limitations which can perfected by the next research. The limitationsare the population and sample used are inactive customer for the last two years in PT. BCA, Tbk so it still not lead to perfect switching behavior. For the next research it would be better if the population an sample are the real customer who has done switching behavior so it will be discovered the cause of switching behavior and why they do not have any account anymore in PT. BCA, Tbk branch malang.

\section{ACKNOWLEDGEMENT}

The author would like to thank Mr. Dodi as Head of Studies Program Mrs. Rofiaty and Mr. Sudjatno, as a supervisor, Mr. Amir Basri as Head of Branch Office Unit BCA Malang, which helped a lot during the writing process.

\section{REFERENCES}

[1]. Kasmir, 2014, Dasar-dasar Perbankan, edisi revisi 2014, Raja GrafindoPersada.

[2]. Media Investor Daily Indonesia, (2016, Ketahanan industry perbankan di Era MEA, Media Investor Daily Indonesia, 28 Maret 2016, Hal : 19

[3]. Manrai,2007, A Field Study of Customer Switching Behavior For Bank Services,Journal of Retailing and Consumer Service14.208-215.

[4]. Philip, Gerrard,j,dan Barton Cunningham, 2004 Customer Switching Behavior In The Asian Banking Maret, The Journal of Service Marketing, 18.2/3: 215-223. Research.9.3:83-89.

[5]. Clemes, et al, 2010, Customer Switching Behavior In The Chinese Reatail Banking Industry, The International Journal Of Bank Marketing.28.7:519-546.

[6]. Kotler and .Keller, 2009, Manajemen Pemasaran, PT.Indeks PT.Macanan Jaya Cemerlang.

[7]. Tjiptono. F, 2001 Total Quality Management, edisi revisi, CV Adi offset Yogyakarta.

[8]. Chakravarty,S,et al. 2004 Relationship and Individuals Bank Switching Behavior,Journal of Economic Psychology25.507-527.

[9]. Kasmir, 2014, Manajemen Perbankan, edisi revisi 2014, Raja Grafindo Persada.

[10]. Gurjeet, et al. 2012,Exploring Customer Switching Intentions Through Relationship 
Marketing Paradigm, The International Journal of Bank Marketing30.4:280-302.

[11]. Keaveney, 1995, Customer Switching Behavior In Industries: An Exploratory Study, Journal of Marketing, 59.2:71.

[12]. Indriantono, N., dan Supomo, B., 2002, Metodologi Penelitian Bisnis untuk Akuntansi dan Manajemen, Edisi Pertama, Cetakan Kedua, Penerbit BPFE, Yogyakarta.

[13]. Ferdinand A.T, 2014, Metode Penelitian Manajemen, Seri pustaka Kunci 12/2014.BP Undip ISBN 979-704-254-5.

[14]. Ma'ruf, 2015, Metodologi Penelitian Kuantitatif, CV.Aswaja Pressindo.

[15]. Abdillah, W, dan Jogiyanto. 2015. Partial Least Square (PLS), Al ternatif Structure Equation Modeling (SEM) dalam Penelitian Bisnis. Yogyakarta, CV Andi Offset.

[16]. Ghozali, Imam. 2011. Partial Least Squares.Konsep Teknik dan Aplikasi.Semarang: Badan Penerbit Universitas Diponegoro .

[17]. Hair, et al. 2013. A Primer on Partial Least Squares Structural Equation Modeling (PLSSEM).Los Angles:Sage 